\title{
Carbon and ancient climates
}

The palaeoceanography and climate science communities have experienced a wrenching blow with the loss of an exceptional researcher, teacher and personality - Mark Pagani. Mark passed away surrounded by his family on November 17, 2016 at the age of 56 after a courageous battle with an aggressive type of lymphoma. He is survived by his beloved spouse, Teresa, and their two children, Ruben and Kyla.

Mark received his PhD from The Pennsylvania State University in 1998, after which he spent several years at the University of California, Santa Cruz as a postdoctoral scholar and researcher. Since 2002, he was a professor at Yale University in New Haven, Connecticut. His published papers form an extraordinarily deep and insightful legacy of research, which span the fields of palaeoclimatology, palaeoceanography and organic geochemistry. Among the most well-known are his reconstructions of atmospheric $\mathrm{CO}_{2}$ levels over the past 45 million years, derived from the carbon isotopic composition of alkenones - lipids produced by phytoplankton. Inferring $\mathrm{CO}_{2}$ concentrations deep into geologic time is no small feat, but it is critical if we are to understand how the Earth responds to changing levels of greenhouse gases. Mark made a lasting contribution through his pioneering applications of the alkenone- $p_{\mathrm{CO}_{2}}$ technique, by applying it alongside many other proxy records and by delving deeply into its uncertainties such as the effects of growth rate, cell size and carbon-concentrating mechanisms. Mark's exceptional scientific career was recognized this year when he was elected a Fellow of the American Geophysical Union.

Mark interrogated the causes and consequences of climate change across the Cenozoic era, including the dynamics of warm climate states such as the early Eocene, characterized by no ice sheets and palm trees at the poles, and large climate shifts such as the EoceneOligocene transition. The relevance to future climate is obvious, as current $p_{\mathrm{CO}_{2}}$ levels have already reached what Mark inferred for the Pliocene, and model projections indicate that we could achieve

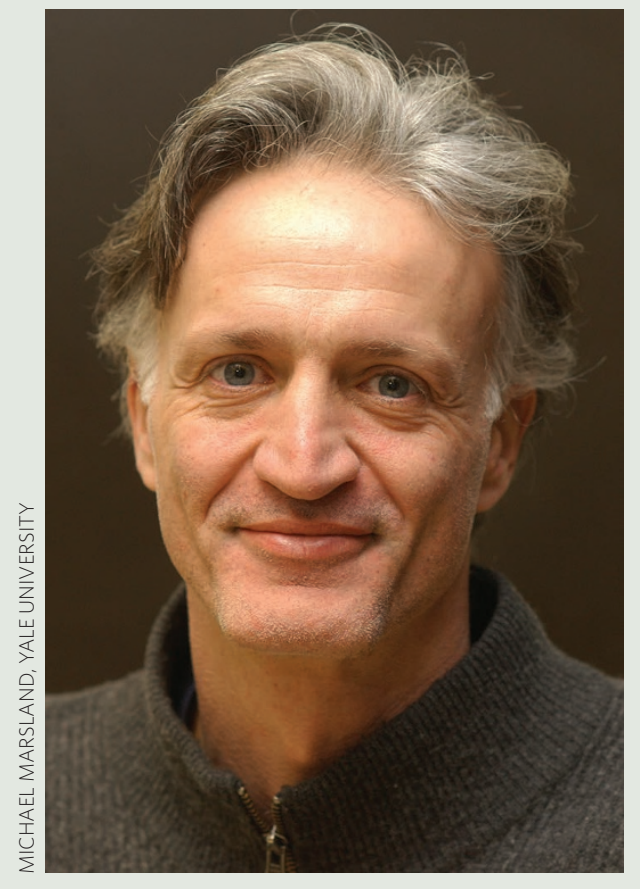

their latest album, Anthropomorphic, epitomizes Mark's artistic and creative energy, with haunting melodies and vocals exploring pain, beauty and death.

Anyone who has met Mark is not likely to forget him. He was often described with superlatives - both positive and negative - and he was notorious for saying exactly what was on his mind with piercing candour. His comments often elicited astonishment and sometimes cost him working relationships with colleagues and friendships. But Mark was also inspiring and generous, especially to young scientists: he opened windows of opportunity at critical career junctions and encouraged students and postdocs to interrogate and innovate. He interacted with everyone equally and genuinely, and often on a deep emotional level. When agitated, Mark's eyes would take on a somewhat terrifying lucidity as he spoke about two inches from your face. When good news came along, it was ecstatic hugs all around. Whether one thought of Mark as a friend, colleague, hero, provocateur or rival, he enriched our community and our science in a way that is impossible to forget and even harder to replace.

We imagine that if Mark had a parting message for us, it would be: "let us not succumb to complacency" (only, it would be embellished with expletives). Let us honour Mark's memory by relentlessly questioning assumptions, infusing our scientific enterprises with joy and passion, combating ignorance with knowledge and grace, and by turning the volume knob up just a little bit higher.

\section{JESSICA E. TIERNEY \&}

KATHERINE H. FREEMAN

\section{Jessica E. Tierney is in the Department of Geosciences, University of Arizona, 1040 E 4th St Tucson, Arizona 85721, USA. Katherine H. Freeman is in the Department of Geosciences, Pennsylvania State University, 235 Deike Building, University Park, \\ Pennsylvania 16802, USA. \\ e-mail: jesst@email.arizona.edu; khf4@psu.edu}

Corrected after print: 6 January 2017 


\section{Correction}

In the Obituary 'Carbon and ancient climates' (Nat. Geosci. 10, 6; 2017), the names of Mark

Pagani's children were spelled incorrectly. This has been corrected online on 6 January 2017. 